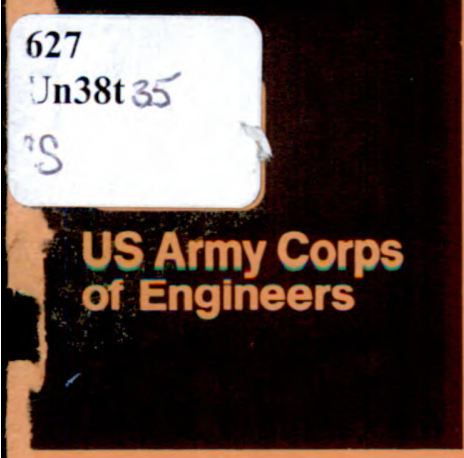

REPAIR, EVALUATION, MAINTENANCE, AND REHABILITATION RESEARCH PROGRAM

TECHNICAL REPORT REMR-CS-16

\title{
REPAIR OF DAM INTAKE STRUCTURES AND CONDUITS: CASE HISTORIES
}

by

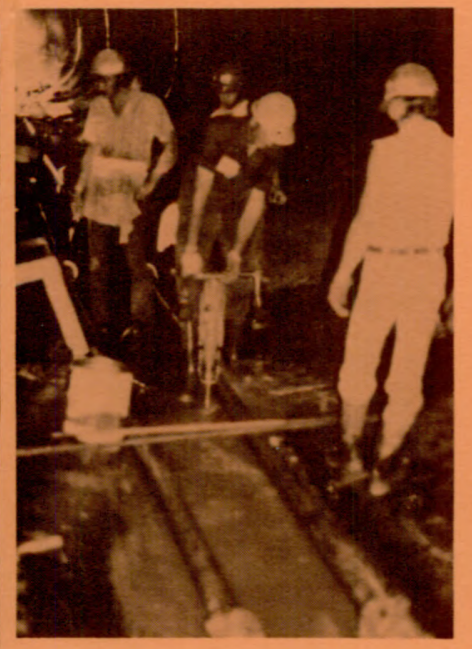

Roy L. Campbell, Sr., Dennis L. Bean

Structures Laboratory

DEPARTMENT OF THE ARMY

Waterways Experiment Station, Corps of Engineers

PO Box 631, Vicksburg, Mississippi 39180-0631
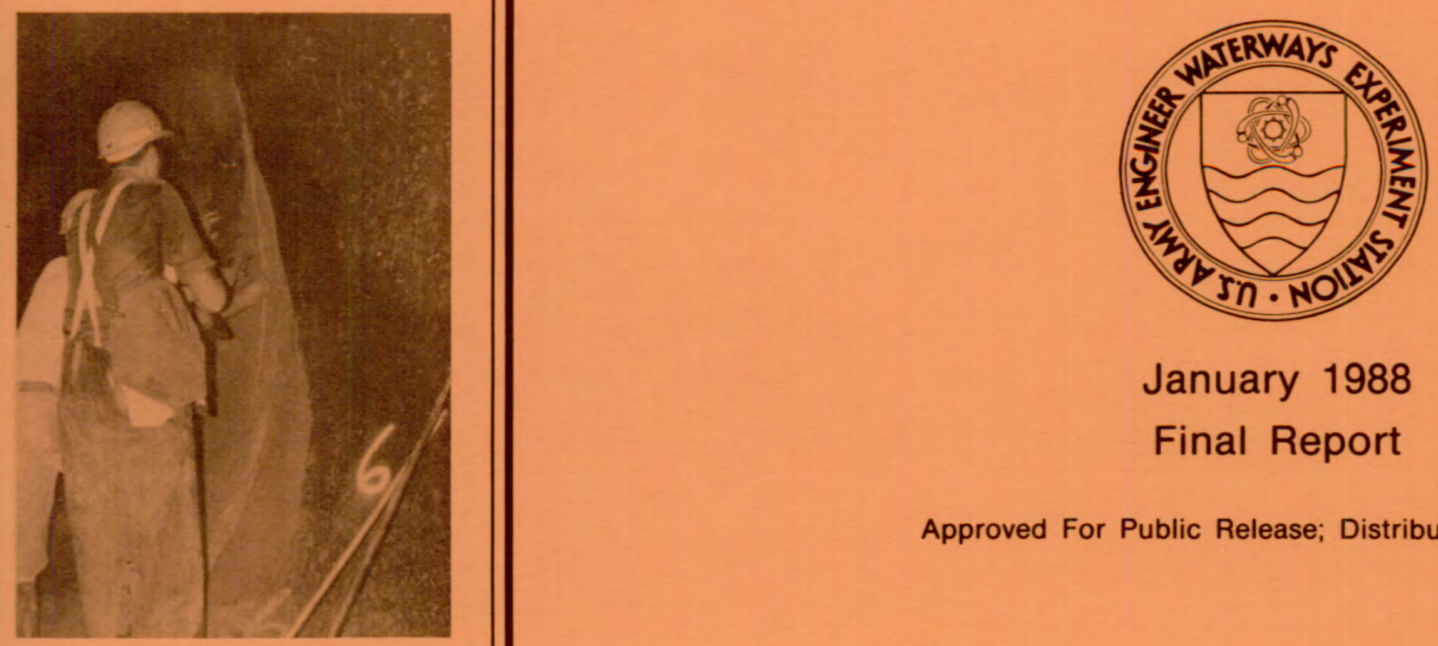

January 1988

Final Report

Approved For Public Release; Distribution Unlimited

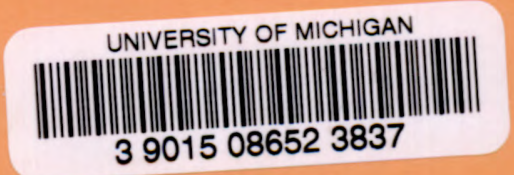

Prepared for DEPARTMENT OF THE ARMY US Army Corps of Engineers Washington, DC 20314-1000

Under Civil Works Research Work Unit 32304 